Budi Aspani, Kompetensi Absolut Dan Relatif Peradilan Tata Usaha Negara Menurut UndangUndang Nomor 5 Tahun 1986 Jo. Undang-Undang Nomor 9 Tahun 2004

Halaman 344-352

\title{
KOMPETENSI ABSOLUT DAN RELATIF PERADILAN TATA USAHA NEGARA MENURUT UNDANG-UNDANG NOMOR 5 TAHUN 1986 Jo. UNDANG-UNDANG NOMOR 9 TAHUN 2004.
}

\author{
Budi Aspani \\ Fakultas Hukum Universitas Palembang \\ e-mail; budiaspani@yahoo.com
}

\begin{abstract}
Indonesia is constitutionally constitutional state and requires the government through its apparatus in the field of State Administration to play a positive active role in all aspects of people's lives to achieve the prosperity of their people. Within this framework, it is not uncommon for a dispute to be caused by actions from the government in the form of irregularities, thus violating the human rights of its citizens. Strictly speaking, these deviations constitute government actions that are detrimental to those affected by the decision, in this case the people. The foregoing raises problems namely; whether any decision of the State Administration or Agency that causes harm to a person or legal entity can be submitted and sued as a dispute to the State Administrative Court and administrative efforts in which the decision can be sued again through the State Administrative Court. In this study the authors use the method of normative law research (normative law research) and by using primary, secondary and tertiary legal materials. Normative legal research examines laws that are conceptualized as the norms or principles that apply in society, and become a reference for each person's behavior. Management and analysis of data is done in a qualitative way that is analyzing library data to produce descriptive data. After conducting discussions on the existing problems, it can be concluded, Each decision of the State Administration Agency or officials that causes harm to civil legal persons or entities can be submitted and sued as a dispute to the State Administrative Court. Its relative competency is related to the place of residence or jurisdiction of the court itself, as well as the parties to the dispute. Whereas the absolute competence can be seen from the point of view of the basis of disputes, which is due to the issuance of written provisions by the State Administrative Court or Agency. Administrative efforts in resolving state administrative disputes are known as administrative channels or efforts, whether in the form of administrative appeals or objections. In accordance with the basis of our country's philosophy of Pancasila, then the state administrative disputes should be resolved as far as possible through administrative efforts, which are more deliberative in reaching consensus. But if all available administrative efforts have been used, it turns out that the disputing parties remain unsatisfied, then the matter is raised and sued through the State Administrative Court.
\end{abstract}

\section{Keywords: Competence; State Administrative Court; State law}

\section{ABSTRAK}

Secara konstitusional negara Indonesia merupakan negara hukum dan mewajibkan pemerintah melalui aparaturnya di bidang Tata Usaha Negara berperan positif aktif dalam segala aspek kehidupan masyarakat untuk mencapai kemakmuran rakyatnya. Di dalam rangka itulah, tidak jarang terjadi suatu sengketa yang diakibatkan oleh tindakan-tindakan dari pemerintah yang berupa penyimpangan-penyimpangan, sehingga melanggar hak-hak asasi warganya. Tegasnya penyimpangan-penyimpangan itu merupakan tindakan pemerintah yang merugikan bagi yang terkena keputusan, dalam hal ini rakyat. Hal tersebut di atas menimbulkan permasalahan yakni; apakah setiap keputusan dari Badan atau Pejabat Tata Usaha Negara yang menimbulkan kerugian bagi orang atau badan hukum perdata dapat diajukan dan digugat sebagai suatu sengketa ke Peradilan Tata Usaha Negara serta upaya-upaya administratif yang mana keputusannya dapat digugat kembali melalui Peradilan Tata Usaha Negara. Di dalam penelitian ini penulis menggunakan metode peneitian hukum normatif (normative law research) dan dengan menggunakan bahan hukum primer, sekunder dan tersier. Penelitian hukum normatif mengkaji hukum yang dikonsepsikan sebagai norma atau kaedah yang berlaku dalam masyarakat, dan menjadi acuan prilaku setiap orang. Pengelolaan dan analisis data dilakukan dengan cara kualitatif yaitu menganalisis data kepustakaan untuk menghasilkan data deskriptif.Setelah melakukan pembahasan terhadap permasalahan yang ada, maka 
Budi Aspani, Kompetensi Absolut Dan Relatif Peradilan Tata Usaha Negara Menurut UndangUndang Nomor 5 Tahun 1986 Jo. Undang-Undang Nomor 9 Tahun 2004

Halaman 344-352

dapat disimpulkan, Tiap-tiap keputusan dari Badan atau pejabat Tata Usaha Negara yang menimbulkan kerugian bagi orang atau badan hukum perdata dapat diajukan dan digugat sebagai suatu sengketa ke Peradilan Tata Usaha Negara. Kompetensi relatifnya dikaitkan dengan tempat kedudukan atau wilayah hukum pengadilan itu sendiri, serta pihak-pihak yang bersengketa. Sedangkan kompetensi absolutnya dapat dilihat dari sudut adanya pangkal sengketa, yaitu berhubung dikeluarkannya ketetapan tertulis oleh Badan atau Peradilan Tata Usaha Negara. Upaya administratif dalam menyelesaikan sengketa tata usaha negara dikenal adanya jalur atau upaya administratif, baik berupa banding administratif ataupun keberatan. Sesuai dengan dasar falsafah negara kita Pancasila, maka hendaknya sengketa tata usaha negara sedapat mungkin diselesaikan melalui upaya administratif, yang lebih bersifat musyawarah untuk mencapai mufakat. Tetapi bila keseluruhan upaya administratif yang tersedia telah digunakan, ternyata pihak yang bersengketa tetap belum merasa puas, maka barulah masalah itu diajukan dan digugat melalui Peradilan Tata Usaha Negara.

Kata Kunci: Kompetensi; Peradilan Tata Usaha Negara; Negara Hukum

\section{PENDAHULUAN}

\section{A. Latar Belakang}

Di dalam pasal 1 ayat (3) UndangUndang Dasar 1945 secara tegas menyebutkan bahwa negara Indonesia adalah negara hukum. Kemudian di dalam alinea ke-IV Pembukaan Undang-Undang Dasar 1945 dirumuskan tujuan negara Indonesia yang hendak dicapai yakni melindungi segenap bangsa Indonesia dan seluruh tumpah darah Indonesia dan untuk memajukan kesejahteraan umum, mencerdaskan kehidupan bangsa dan ikut melaksanakan ketertiban dunia yang berdasarkan kemerdekaan, perdamaian abadi dan keadilan sosial.

Dengan demikian dapat disimpulkan bahwa secara konstitusionil negara Indonesia merupakan negara yang berlandasarkan kemakmuran dan berlandaskan Pancasila, yang dalam upaya untuk mencapai tujuan tersebut sesuai dengan sistem yang dianut dalam UndangUndang Dasar 1945 mewajibkan pemerintah melalui aparaturnya di bidang Tata Usaha Negara, turut serta berperan positif aktif dalam segala aspek kehidupan masyarakat.

Dalam melaksanakan tugasnya secara aktif, pemerintah melakukan suatu perbuatan penetapan (Beschikking Handeling) yang menghasilkan suatu ketetapan (Beschikking). Didalam rangka itulah, tidak jarang terjadi suatu sengketa yang diakibatkan oleh tindakan-tindakan dari pemerintah yang berupa penyimpangan-penyimpangan, sehingga melanggar hak-hak dan kewajiban asasi manusia. Serta mengganggu keseimbangan antara kepentingan individu dan kepentingan umum. Tegasnya penyimpangan-penyimpangan itu merupakan tindakan pemerintah yang merugikan bagi terkena keputusan, dalam hal ini rakyat.

Untuk keperluan itu pencari keadilan mendapatkan tempatnya di Pengadilan Administrasi atau Pengadilan Tata Usaha Negara. “... yang dapat menampung dan menyelesaikan perkaraperkara yang berhubungan dengan pelanggaran-pelanggaran yang dilakukan oleh Pejabat atau aparat negara, maupun memberikan kepastian hukum bagi setiap pegawai negeri ..." 1

Pemerintah berwenang untuk melakukan perbuatan tata usaha negara yang dapat dikelompokkan dalam tiga macam perbuatan, yaitu: ${ }^{2}$

Mengeluarkan Keputusan (beschikking);

Mengeluarkan Peraturan (regeling);

Melakukan Perbuatan Materiil (material daad).

Dari ketiga macam perbuatan tata usaha negara itu yang masuk dalam kompetensi Peradilan Tata Usaha Negara dalam arti tindakan atau perbuatan badan eksekutif yang dapat dinilai oleh Peradilan

1 Departemen Penerangan RI, Pidato Kenegaraan Presiden ..., Terkutip: Sjachran Basah, HAPLA, Rajawali Pers, 1987, hal. 33.

2 Padmo Wahyono, Undang-undang Nomor 5 Tahun 1986 serta penjelasannya, Ghalia Indonesia, Jakarta, 1987, hal. 13.

Volume 16 Nomor 3. Bulan September Tahun 2018 
Budi Aspani, Kompetensi Absolut Dan Relatif Peradilan Tata Usaha Negara Menurut UndangUndang Nomor 5 Tahun 1986 Jo. Undang-Undang Nomor 9 Tahun 2004

Halaman 344-352

Tata Usaha Negara adalah perbuatan mengeluarkan keputusan. Kendati demikian tidak berarti bahwa perbuatan tata usaha negara yang kedua ataupun yang ketiga itu tidak dapat dinilai oleh pengadilan. Jadi ini berarti bahwa pada dasarnya semua perbuatan dari pemerintah itu dapat dinilai oleh pengadilan, walaupun yang menilai tidak termasuk dalam lingkungan Peradilan Tata Usaha Negara.

Berdasarkan apa yang telah penulis uraikan diatas maka penulis tertarik untuk menuangkan permasalahan yang ada dalam bentuk karya ilmiah dengan judul: “ KOMPETENSI ABSOLUT DAN RELATIF PERADILAN TATA USAHA NEGARA MENURUT UNDANGUNDANG NOMOR 5 TAHUN 1986 Jo. UU NOMOR 9 TAHUN 2004".

\section{B. PERmasalahan}

Bertitik tolak dari apa yang telah penulis uraikan di atas, penulis menuangkan permasalahan sebagai berikut :

Apakah setiap keputusan dari Badan atau Pejabat Tata Usaha Negara yang menimbulkan kerugian bagi orang atau badan hukum perdata dapat diajukan dan digugat sebagai suatu sengketa ke Peradilan Tata Usaha Negara?

Upaya-upaya administratif yang mana keputusannya dapat digugat kembali melalui Peradilan Tata Usaha Negara?

\section{Ruang Lingkup Pembahasan}

Dalam pembahasan nanti penulis hanya akan membahas mengenai apa yang menjadi ruang lingkup dalam kompetensi absolut dan relatif dalam lingkungan Peradilan Tata Usaha Negara menurut Undang - Ungan nomor 5 Tahun 1986 Jo.Undang-undang Nomor 9 Tahun 2004, dalam kaitannya untuk memberikan perlindungan kepada rakyat pencari keadilan.

\section{Metode Penelitian \\ 1. Pendekatan masalah}

Untuk dapat memberikan penjelasan terhadap masalah yang jadi pokok pembahasan dalam penulisan ini maka pendekatan masalah yang dilakukan dengan cara pendekatan yuridis, yaitu dengan menginventarisasi permasalahan hukumnya. Sedangkan metode penulisan digunakan metode analisis desktriptif, maksud dari data yang ada dianalisa serta dijelaskan guna lebih mempertajam masalah yang dihadapi.

\section{Sumber data}

Data yang digunakan dalam menyusun penulisan ini diperoleh dari kepustakaan berupa buku-buku, literatur dan perundang-undangan serta yurisprudensi yang ada hubungannya dengan permasalahan.

\section{Prosedur pengumpulan dan pengolahan data}

Data-data yang telah terkumpul itu diolah dengan memisahkannya dalam babbab dan sub-sub bab, sehingga memudahkan penulisan ini serta mencegah terjadinya kekacauan dalam penulisannya.

\section{Analisis data}

Data yang ada itu dianalisa sesuai dengan permasalahan, kemudian diuraikan dan disusun, dijelaskan secara sistematis dengan menggunakan metode deskriptif.

\section{PEMBAHASAN}

\section{A. Pengertian dan Macam-macam Kompetensi}

Istilah kompetensi berasal dari bahasa latin di abad menengah, yaitu "Competia" yang berarti hetgeen an iemand toekomt yang diartikan "apa yang menjadi wewenang seseorang". 3

Yang lebih lanjut oleh Sjachran Basah istilah itu diterjemahkan, kompetensi adalah sebagai kewenangan, kekuasaan atau hak yang dikaitkan dengan badan

\footnotetext{
${ }^{3}$ Sjachran Basah, Eksistensi dan Tolak Ukur Badan Peradilan Administrasi di Indonesia, Alumni, Bandung, 1985, hal. 65
} 
Budi Aspani, Kompetensi Absolut Dan Relatif Peradilan Tata Usaha Negara Menurut UndangUndang Nomor 5 Tahun 1986 Jo. Undang-Undang Nomor 9 Tahun 2004

Halaman 344-352

yang menjalankan kekuasaan kehakiman, sehingga badan itu menjadi wewenang.

Jadi kompetensi merupakan pemberian kekuasaan, kewenangan atau hak kepada badan dan atau pengadilan yang melakukan peradilan. Hal ini penting agar suatu permohonan atau gugatan, yang disampaikan kepada badan atau pengadilan dapat diperiksa dan diputus oleh badan yang berwenang. Untuk itu terutama harus diperhatikan kompeten atau tidaknya pengadilan tersebut memeriksa suatu perkara. Mengenai kekuasaan atau kewenangan (kompetensi) suatu badan peradilan untuk mengadili dalam ilmu hukum dikenal 2 (dua) macam kekuasaan, yaitu:

Kekuasaan berdasarkan peraturan hukum mengenai pemberian kekuasan mengadili (atribusi) kepada suatu pengadilan, bukan kepada pengadilan lain; Kekuasaan berdasarkan peraturan hukum mengenai pemberian kekuasaan mengadili (distribusi) di antara masing-masing pengadilan.

Yang disebut pertama adalah kompetensi absolut. Dikatakan demikian karena kewenangan (kompetensi) pengadilan untuk mengadili suatu perkara menurut materi (obyek) perkaranya. Sedangkan yang kedua adalah kompetensi relatif. Dikatakan demikian karena berhubungan dengan kewenangan pengadilan untuk mengadili suatu perkara sesuai wilayahnya atau ditentukan oleh batas daerah hukum yang menjadi kewenangannya. Demikian pula menurut Prof. Wirjono Prodjodikoro, di dalam kewenangan atau kekuasaan pengadilan itu tercakup dua masalah, yaitu: ${ }^{4}$

1. Attribute (pemberian): apakah pengadilan negeri perdata umumnya (dan) bukan lain macam pengadilan atau badan kekuasaan lain (yang) berkuasa memeriksa perkara semacam, yang

\footnotetext{
${ }^{4}$ Ibid, hal. 65.
}

dimaksudkan dalam permohonan gugat?

2. Distributie (pembagian): apakah pengadilan negeri yang disebut dalam permohonan gugat (dan) bukan pengadilan negeri lain (yang) berkuasa memeriksa perkara itu, yang dimaksudkan dalam permohonan gugat?

Untuk lebih jelasnya mengenai batasan kewenangan pengadilan itu, di bawah ini penulis akan uraikan secara singkat mengenai kompetensi absolut dan relatif tersebut sebagai berikut:

a. Kompetensi Absolut

Kompetensi absolut adalah kewenangan suatu badan pengadilan untuk mengadili suatu perkara menurut materi (obyek)nya. Dikatakan demikian karena hanya dimiliki oleh pengadilan tertentu dan tidak kepada pengadilan yang lain. Hal ini sesuai dengan obyek yang dipersengketakan oleh para pihaknya.

b. Kompetensi Relatif

Kompetensi relatif suatu badan pengadilan itu ditentukan oleh batas daerah hukum yang menjadi kewenangannya. Suatu badan pengadilan dinyatakan berwenang untuk memeriksa suatu sengketa apabila salah satu pihaknya yang bersengketa itu baik sebagai penggugat atau tergugat berkediaman di salah satu daerah hukum yang menjadi wilayah hukum pengadilan tersebut.

\section{B. Sengketa Tata Usaha Negara} Pangkal Sengketa Tata Usaha Negara

Sebagai tolak ukur dari pangkal sengketa tata usaha negara yakni sengketa administrasi yang diakibatkan oleh ketetapan sebagai hasil penetapan administrasi negara. Hal ini dapat ditemui pada rumusan pasal 1 ayat 4 Undang- 
Budi Aspani, Kompetensi Absolut Dan Relatif Peradilan Tata Usaha Negara Menurut UndangUndang Nomor 5 Tahun 1986 Jo. Undang-Undang Nomor 9 Tahun 2004

Halaman 344-352

undang Nomor 5 Tahun 1986 yakni: "Sengketa Tata Usaha Negara adalah sengketa yang timbul dalam bidang tata usaha negara antara orang atau badan hukum perdata dengan Badan atau Pejabat Tata Usaha Negara, baik di pusat maupun di daerah sebagai akibat dikeluarkannya keputusan tata usaha negara, termasuk sengketa kepegawaian berdasarkan peraturan perundang-undangan yang berlaku".

Dari rumusan tersebut dapat disimpulkan bahwa sengketa tata usaha negara terdiri dari:

Subyek yang bersengketa, adalah orang atau badan hukum perdata di satu pihak dan Badan atau Pejabat Tata Usaha Negara.

Obyek sengketa, adalah keputusan yang dikeluarkan oleh Badan atau Pejabat Tata Usaha Negara.

Menurut pendapat MH. Muhjad, dalam bukunya "Beberapa Masalah Tentang Peradilan Tata Usaha Negara di Indonesia" menyebutkan bahwa: Sengketa yang terjadi itu haruslah sengketa tata usaha negara yang dapat mencakup tindakan atau sikap diamnya Badan atau Pejabat Tata Usaha Negara, yang berupa tindakan tidak tepat, melanggar undangundang, tidak efisien (tidak bijaksana) dan melanggar hukum, seperti:

melampaui batas kekuasaannya (exces de pouvoir)

penyimpangan kekuasaan (detournament de pouvoir)

penyalahgunaan kekuasaan (abus de pouvoir)

penyalahgunaan hak (abus de droit)

Sedangkan menurut Benjamin Mangkoedilaga, yang dapat digugat atau menjadi sengketa di depan Peradilan Tata Usaha Negara adalah suatu ketetapan tertulis yang berdasarkan suatu peraturan perundang-undangan yang berlaku yang menimbulkan akibat hukum bagi seseorang atau badan hukum perdata.
Kemudian hal-hal yang diajukan sebagai sengketa itu haruslah berada dalam lapangan hukum publik, bukan terletak dalam lapangan hukum privat.

Dengan singkat dapat dikatakan atau disimpulkan bahwa yang menjadi sebab timbulnya sengketa tata usaha negara adalah adanya ketetapan-ketetapan atau peraturan pelaksanaannya yang dikeluarkan oleh pemerintah dalam melaksanakan tugas servis publik, yaitu suatu tindakan yang bersifat unilateral terhadap masyarakat. ${ }^{5}$

\section{Para Pihak dalam Sengketa Tata Usaha Negara}

Salah satu isi dari unsur-unsur peradilan pada umumnya mensyaratkan adanya para pihak di dalam suatu sengketa. Dalam hal ini yang dimaksudkan dengan para pihak yaitu subyek-subyek yang saling berselisih.

Demikian pula halnya dalam peradilan administrasi murni, dicantumkan unsurunsur dari peradilan administrasi sekurang-kurangnya salah satu pihak yang berselisih harus administrasi negara. Walaupun demikian tidak menutup kemungkinan bahwa para pihak itu kesemuanya adalah administrasi negara. Dalam perkara administrasi, akan terdapat subyek selaku pihak yang bersengketa, yang dapat dibedakan secara intern dan secara ekstern dan salah satunya haruslah Badan atau Pejabat Tata Usaha Negara.

Dikatakan secara intern karena sengketa itu terjadi antara dua pihak yang samasama termasuk administrasi negara yang pada umumnya merupakan persoalan kompetensi. Sedangkan secara ekstern sengketa itu terjadi antara administrasi negara dengan rakyat yang disebabkan oleh ketetapan. Misalnya, di bidangbidang pertanahan, perizinan, perpajakan,

5 Benjamin Mangkodilaga, Kompetensi Relatif dan Absolut Pengadilan Dalam Lingkungan Peradilan Tata Usaha Negara, Angkasa, Bandung, 1986, hal. 25 . 
Budi Aspani, Kompetensi Absolut Dan Relatif Peradilan Tata Usaha Negara Menurut UndangUndang Nomor 5 Tahun 1986 Jo. Undang-Undang Nomor 9 Tahun 2004

Halaman 344-352

bea cukai dan kepegawaian yang menimbulkan kerugian kepada rakyat.

\section{Penyelesaian Sengketa Tata Usaha Negara}

Menurut Undang-undang Nomor 5 Tahun 1986, sengketa di bidang tata usaha negara yang timbul antara orang perorangan dengan Badan atau Peradilan Tata Usaha Negara dapat diselesaikan menurut 2 (dua) jalur, yaitu jalur upaya administratif dan jalur pengajuan gugatan ke Peradilan Tata Usaha Negara atau upaya peradilan.

Berikut penulis akan menguraikan kedua jalur penyelesaian sengketa di bidang tata usaha negara itu sebagai berikut:

\section{E. Upaya Administratif}

Upaya administratif adalah suatu upaya yang disediakan bagi seseorang atau badan hukum perdata untuk mengajukan keberatan atau suatu permohonan kepada Badan atau Peradilan Tata Usaha Negara supaya membatalkan atau mengubah suatu keputusan yang telah dikeluarkan oleh Badan atau Peradilan Tata Usaha Negara tersebut dengan alasan bahwa keputusan itu tidaklah sah atau tidak berdasarkan hukum.

Mengenai upaya administratif ini diatur perumusannya dalam pasal 48 Undangundang Nomor 5 Tahun 1986. Pasal 48 ayat 1 Undang-undang Nomor 5 Tahun 1986 menyatakan bahwa:

"Dalam hal suatu Badan atau Peradilan Tata Usaha Negara diberi wewenang oleh atau berdasarkan peraturan perundang-undangan untuk menyelesaikan secara administratif sengketa Tata Usaha Negara tertentu, maka sengketa tata usaha negara tersebut haruslah diselesaikan melalui upaya administratif yang tersedia".

Jadi upaya administratif adalah suatu pengawasan yang dilakukan oleh organ di lingkungan pemerintah sendiri. Dengan demikian wewenang eksekutiflah yang nanti akan melaksanakannya, bukan wewenang dari badan yudikatif.
Adapun menurut penjelasan pasal 48 ayat 1 Undang-undang Nomor 5 Tahun 1986, upaya administratif itu pada dasarnya dapat dibedakan ke dalam 2 (dua) golongan, yaitu:

Banding Administratif

Keberatan

Adapun yang dimaksud dengan banding administratif itu adalah penyelesaian sengketa tata usaha negara yang dilakukan oleh instansi atasan atau instansi lain yang mengeluarkan keputusan yang bersangkutan. Sedangkan yang dimaksud dengan keberatan adalah suatu penyelesaian sengketa tata usaha negara yang dilakukan sendiri oleh Badan atau Peradilan Tata Usaha Negara yang mengeluarkan keputusan tersebut.

Berbeda dengan prosedur yang ditempuh melalui Peradilan Tata Usaha Negara, maka dalam prosedur banding administratif atau keberatan itu dilakukan penilaian yang lengkap dan oleh instansi yang memutuskan sengketa, baik dari segi penerapan hukum maupun dari segi kebijaksanaan. Sedangkan dalam atau melalui Peradilan Tata Usaha Negara yang dinilai semata-mata hanya dari segi penerapan hukumnya saja.

Dalam penyelesaian sengketa tata usaha negara, upaya administratif lebih bersifat musyawarah untuk mencapai mufakat dari pada secara langsung menggugat Badan atau Peradilan Tata Usaha Negara yang terlalu bersifat konfrontatif antara rakyat dengan Badan atau Peradilan Tata Usaha Negara, yang sedapat mungkin harus dihindari sesuai dengan dasar falsafah negara kita, Pancasila.

Setelah seluruh upaya administratif yang tersedia digunakan, tetapi pihak yang bersangkutan masih tetap merasa belum puas, barulah masalah tersebut diajukan dan digugat melalui Peradilan Tata Usaha Negara.

\section{F. Upaya Peradilan}


Budi Aspani, Kompetensi Absolut Dan Relatif Peradilan Tata Usaha Negara Menurut UndangUndang Nomor 5 Tahun 1986 Jo. Undang-Undang Nomor 9 Tahun 2004

Halaman 344-352

Berdasarkan prinsip "keserasian hubungan atas dasar asas kerukunan", tidak berarti bahwa antara pemerintah dengan rakyatnya tidak mungkin terjadi sengketa. Oleh karena itu yang terbaik jalannya adalah mencegah adanya sengketa. Namun, betapapun segala upaya untuk mencegah timbuhnya sengketa telah dilakukan, namun tetap juga terjadi sengketa, maka jalan penyelesaiannya yang terbaik dan utama adalah melalui jalan damai atau musyawarah. Penyelesaian secara damai adalah yang paling ideal sesuai dengan dasar falsafah negara, yaitu Pancasila.

Penyelesaian secara damai tidak berari meninggalkan prinsip-prinsip dan aturan hukum yang berlaku, tetapi pihak yang bersengketa secara aktif mencari dan akhirnya menyadari prinsip dan ketentuan hukum yang sebenarnya mengenai hal yang dipersengketakan. Dengan cara yang demikian tidak ada istilah menang kalah, tetapi saling pengertian dan saling menyadari hakekat peraturan perundangundangan yang berlaku.

Penyelesaian sengketa tata usaha negara melalui Peradilan Tata Usaha Negara hendaknya merupakan sarana terakhir, artinya tempuhlah pertama-tama penyelesaian secara damai terlebih dahulu, setelah usaha perdamaian tersebut ternyata tidak berhasil, barulah ditempuh jalan yang terakhir yaitu penyelesaian sengketa melalui Peradilan Tata Usaha Negara. Hal ini dapat ditemui dalam rumusan pasal 48 ayat 2 Undang-undang Nomor 5 Tahun 1986. Adapun isi pasal itu adalah: "Pengadilan baru berwenang memeriksa, memutus dan menyelesaikan sengketa tata usaha negara sebagaimana dimaksud dalam ayat (1), jika seluruh upaya administratif yang bersangkutan telah digunakan".

Sesuai dengan fungsi Peradilan Tata Usaha Negara, yaitu memberikan perlindungan kepada rakyat, maka
Undang-undang Nomor 5 Tahun 1986 mencantumkan berbagai ketentuan yang memberikan kemudahan-kemudahan bagi rakyat pencari keadilan. Kemudahankemudahannya itu antara lain:

Pengadilan Tata Usaha Negara berkedudukan di tiap Kotamadya dan Kabupaten. Dengan demikian kedudukannya lebih mudah dijangkau oleh rakyat pencari keadilan (pasal 6 ayat 1)

Bagi yang tidak pandai baca-tulis dalam membuat gugatannya dibantu oleh Panitera Pengadilan (penjelasan pasal 53 ayat 1 )

Penggugat dapat mengajukan gugatannya ke Pengadilan Tata Usaha Negara yang terdekat dengan tempat kediaman untuk kemudian diteruskan ke pengadilan yang berwenang mengadilinya (pasal 54 ayat 3 )

Dalam hal tertentu gugatan dimungkinkan untuk diadili oleh pengadilan yang daerah hukumnya meliputi tempat kediaman penggugat (pasal 54 ayat 4)

Bagi yang tidak mampu, diberi kesempatan untuk berperkara dengan cuma-cuma (pasal 60 ayat 1 )

Jika terdapat kepentingan yang mendesak, Ketua Pengadilan dapat menentukan untuk dilakukan pemeriksaan dengan cara cepat (pasal 98 ayat 1).

Keberadaan Peradilan Tata Usaha Negara diharapkan dapat menyelesaikan sengketa tata usaha negara yang ada di Indonesia secara tuntas, sehingga tercipta aparatuh pemerintah yang diidam-idamkan bersama, yaitu aparatur pemerintah yang profesional, bersih dan berwibawa.

\section{G. Kompetensi Peradilan Tata Usaha Negara}

Dalam ilmu hukum dikenal adanya kompetensi atau kewenangan dari suatu badan pengadilan untuk mengadili suatu perkara, yang dapat dibedakan atas:

1. Kompetensi absolut

2. Kompetensi relatif 
Budi Aspani, Kompetensi Absolut Dan Relatif Peradilan Tata Usaha Negara Menurut UndangUndang Nomor 5 Tahun 1986 Jo. Undang-Undang Nomor 9 Tahun 2004

Halaman 344-352

Kompetensi absolut adalah kewenangan suatu badan pengadilan untuk mengadili suatu perkara menurut materi (obyek) perkaranya. Sedangkan kompetensi relatif adalah kewenangan suatu badan pengadilan untuk mengadili suatu perkara sesuai dengan wilayah hukumnya.

Sama halnya dengan pengadilanpengadilan lainnya, Pengadilan Tata Usaha Negara pun mempunyai kedua macam kompetensi tersebut. Dimana pengaturan kedua kompetensi tersebut telah dirumuskan dalam Undang-undang Nomor 5 Tahun 1986 tentang Peradilan Tata Usaha Negara. Untuk selanjutnya di bawah ini penulis akan uraikan secara singkat mengenai kompetensi absolut dan kompetensi relatif dalam Peradilan Tata Usaha Negara tersebut.

\section{Kompetensi Relatif.}

Dalam pembahasan kompetensi relatif ini, kita dapat kaitkan dengan tempat kedudukan pengadilannya itu sendiri atau dengan para pihak-pihak yang bersengketa. Kompetensi relatif Peradilan Tata Usaha Negara yang dikaitkan dengan pengadilan itu sendiri diatur dalam pasal 6 Undang-undang Nomor 5 Tahun 1986 yang selengkapnya menyatakan sebagai berikut:

Pengadilan Tata Usaha Negara berkedudukan di tiap Kotamadya atau ibukota Kabupaten, dan daerah hukumnya meliputi Kotamadya atau Kabupaten.

Pengadilan Tinggi Tata Usaha Negara berkedudukan di ibukota Propinsi, dan daerah hukumnya meliputi wilayah provinsi.

Sedangkan kompetensi relatif yang berkaitan dengan para pihak yang bersengketa, dapat dilihat pengaturannya yang terdapat di dalam pasal 54 ayat 1 sampai dengan 6, yang menyatakan sebagai berikut:

Gugatan sengketa tata usaha negara diajukan kepada pengadilan yang berwenang yang daerah hukumnya meliputi tempat kedudukan tergugat.

Apabila tergugat lebih dari satu Badan atau Pejabat Tata Usaha Negara dan berkedudukan tidak dalam satu daerah hukum pengadilan, gugatan diajukan kepada pengadilan yang daerah hukumnya meliputi tempat kedudukan salah satu Badan atau Pejabat Tata Usaha Negara.

Dalam hal tempat kedudukan tergugat tidak berada dalam daerah hukum pengadilan tempat kediaman penggugat maka gugatan diajukan ke pengadilan yang daerah hukumnya meliputi tempat kediaman penggugat untuk selanjutnya diteruskan kepada pengadilan yang bersangkutan.

Dalam hal-hal tertentu sesuai dengan sifat sengketa tata usaha negara yang bersangkutan yang diatur dengan peraturan pemerintah, gugatan dapat diajukan kepada pengadilan yang berwenang yang daerah hukumnya meliputi tempat kediaman penggugat.

Apabila penggugat dan tergugat berkedudukan atau berada di luar negeri, gugatan diajukan kepada pengadilan di Jakarta.

Apabila tergugat berkedudukan di dalam negeri dan penggugat di luar negeri, gugatan diajukan kepada pengadilan di tempat kedudukan tergugat.

Selanjutnya di dalam pasal 55 ditegaskan bahwa gugatan sengketa tata usaha negara diajukan kepada pengadilan yang berwenang yang daerah hukumnya meliputi tempat kedudukan tergugat dapat diajukan hanya dalam tenggang waktu sembilan puluh (90) hari terhitung sejak saat diterima atau diumumkannya keputusan tata usaha negara. Akan tetapi dalam hal tergugat tidak berkedudukan dalam daerah hukum pengadilan tempat penggugat, maka menurut pasal 54 ayat 3 Undang-undang Nomor 5 Tahun 1986, gugatan dapat diajukan ke pengadilan yang daerah hukumnya meliputi tempat 
Budi Aspani, Kompetensi Absolut Dan Relatif Peradilan Tata Usaha Negara Menurut UndangUndang Nomor 5 Tahun 1986 Jo. Undang-Undang Nomor 9 Tahun 2004

Halaman 344-352

kediaman penggugat untuk diteruskan kepada pengadilan yang bersangkutan. Bahkan dalam hal-hal tertentu yang akan diatur dengan peraturan pemerintah, gugatan dapat diajukan kepada pengadilan yang berwenang yang daerah hukumnya meliputi tempat penggugat.

Prosedur ini merupakan salah satu kekhususan dari beracara di muka Hakim Pengadilan dalam lingkungan Peradilan Tata Usaha Negara. Di samping untuk memberikan kemudahan bagi penggugat, tetapi juga untuk menjaga ahar tenggang waktu 90 hari bagi pengajuan gugatan tidak dilampaui.

\section{Kompetensi Absolut}

Mengenai kompetensi absolut untuk Pengadilan Tata Usaha Negara dapat dilihat dari sudut adanya pangkal sengketa, yaitu berhubung dikeluarkannya ketetapan tertulis oleh Badan atau Peradilan Tata Usaha Negara, seperti yang diatur dalam pasal 1 butir 3 Undang-undang Nomor 5 Tahun 1986 yang berbunyi: "Keputusan Tata Usaha Negara adalah suatu penetapan tertulis yang dikeluarkan oleh Badan atau Peradilan Tata Usaha Negara yang berisi tindakan hukum tata usaha negara berdasarkan peraturan perundangundangan yang berlaku".

Seperti diketahui, dalam melaksanakan tugas-tugasnya sebagai servis publik, maka tindakan pemerintah itu dapat dinilai oleh pengadilan, artinya setiap tindakan pemerintah dapat digugat di depan pengadilan. Akan tetapi tidak semua tindakan pemerintah dapat diadili oleh Pengadilan Tata Usaha Negara. Lalu timbul permasalahan tindakan pemerintah yang manakah yang menjadi kompetensi absolut Peradilan Tata Usaha Negara?

Menurut Undang-undang Nomor 5 Tahun 1986 kompetensi absolut Peradilan Tata Usaha Negara adalah sengketa tata usaha negara (sesuai dengan objeknya). Sedangkan yang dimaksudkan dengan sengketa tata usaha negara adalah sengketa yang timbul dalam bidang tata usaha negara antara orang atau badan hukum perdata dengan Badan atau Peradilan Tata Usaha Negara, sebagai akibat dikeluarkannya keputusan tata usaha negara.

Disamping adanya ketetapan tertulis yang menjadi pangkal sengketa, ternyata menurut Undang-undang Nomor 5 Tahun 1986 masih terdapat suatu perbuatan yang dianggap merupakan ketetapan tertulis, seperti yang tercantum dalam pasal 3 ayat 1 yang menyatakan "Apabila Badan atau Peradilan Tata Usaha Negara tidak mengeluarkan keputusan yang dimohonkan kepadanya, sedang hal itu menjadi kewajibannya, maka hal tersebut disamakan dengan keputusan tata usaha negara". Disamping itu di dalam pasal 1 butir 3 Undang-undang Nomor 5 Tahun 1986 disinggung tentang syrat keputusan tersebut, yaitu: "Keputusan tata usaha negara tersebut harus mempunyai sifat kongkrit, individu dan final".

Mengenai batasan ketiga sifat tersebut, dapat kita lihat seperti yang tercantum di dalam penjelasan pasal 1 angkat 3 yang menyatakan bahwa, Bersifat kongkrit, artinya objek yang diputuskan dalam keputusan tata usaha negara itu tidak abstrak, tetapi berwujud tertentu atau dapat ditentukan. Bersifat individuil, artinya keputusan tata usaha negara itu tidak ditujukan untuk umum, tetapi tertentu baik alamat maupun hal yang dituju". Bersifat final, artinya sudah definitif dan karenanya dapat menimbulkan akibat hukum".

Adanya persyaratan penetapan tertulis memang kita akui banyak segi kelemahannya, terutama menyangkut masalah waktu yang dibutuhkan cukup panjang, atau mingkin hal ini disebabkan karena melalui proses dan liku-liku yang rumit sehingga dikhawatirkan akan menimbulkan kelambahanan administrasi atau makin derasnya keputusan tak tertulis. 
Budi Aspani, Kompetensi Absolut Dan Relatif Peradilan Tata Usaha Negara Menurut UndangUndang Nomor 5 Tahun 1986 Jo. Undang-Undang Nomor 9 Tahun 2004

Halaman 344-352

Yan lebih khawatir lagi adalah adanya keputusan tertulis atas desakan keputusan tak tertulis. Timbul pertanyaan mengapa Undang-undang Nomor 5 Tahun 1986 membatas kompetensinya hanya pada keputusan tata usaha negara tertulis saja ? Artinya keputusan tata usaha negara secara lisan tidak termasuk objek sengketa tata usaha negara. Alasannya adalah hal ini disebabkan keputusan tata usaha negara tidak tertulis itu sukar untuk dijadikan pegangan, dan sulit untuk dibuktikan, lagi pula mudah untuk disangkal oleh salah satu pihak jika timbul sengketa antara mereka.

Persyaratan tertulis terutama menunjuk pada isi bukan pada bentuknya keputusan tersebut yang dikeluarkan oleh Badan atau Peradilan Tata Usaha Negara. Oleh karena itu sebuah memo atau nota dapat memenuhi syarat tertulis tersebut dan akan merupakan suatu keputusan Badan atau Peradilan Tata Usaha Negara menurut undang-undang ini sudah jelas :

Badan atau Peradilan Tata Usaha Negara mana yang mengeluarkannya;

Maksud serta mengenai hal apa isi tulisan itu;

Kepada siapa tulisan itu ditujukan, dan apa yang ditetapkan di dalamnya.

Persyaratan tertulis itu diharuskan hanya untuk memudahkan saja. Seperti apa yang tercantum dalam penjelasan pasal butir 3 yang menyatakan "Persyaratan tertulis itu diharuskan untuk kemudahan segi pembuktian". Dengan demikian dapat dikatakan kompetensi absolut Peradilan Tata Usaha Negara itu mempunyai ciri-ciri sebagai berikut:

Yang bersengketa, adalah orang atau badan hukum perdata dengan Badan atau Peradilan Tata Usaha Negara;

Obyek sengketa, adalah keputusan tata usaha negara tertulis yang dikeluarkan oleh Badan atau Peradilan Tata Usaha Negara;
Keputusan yang dijadikan obyek sengketa itu berisi tindakan hukum tata usaha negara;

Keputusan yang dijadikan obyek sengketa itu bersifat kongkrit, individuil dan final yang menimbulkan akibat hukum bagi seseorang atau badan hukum perdata.

PENUTUP

Berdasarkan dari keseluruhan uraian-uraian yang telah dikemukakan, di atas, ditarik kesimpulan sebagai berikut:

Tiap-tiap keputusan dari Badan atau pejabat Tata Usaha Negara yang menimbulkan kerugian bagi orang atau badan hukum perdata dapat diajukan dan digugat sebagai suatu sengketa ke Peradilan Tata Usaha Negara adalah dengan dibentuknya Undang-undang Nomor 5 Tahun 1986, merupakan sebagai tonggak pelengkap untuk mewujudkan makna negara hukum yang berdasarkan Pancasila dan Undang-Undang Dasar 1945.

Adapun yang menjadi kompetensi absolut dan relatif Peradilan Tata Usaha Negara yakni: dalam kompetensi relatifnya dikaitkan dengan tempat kedudukan atau wilayah hukum pengadilan itu sendiri, serta pihak-pihak yang bersengketa. Sedangkan kompetensi absolutnya dapat dilihat dari sudut adanya pangkal sengketa, yaitu berhubung dikeluarkannya ketetapan tertulis oleh Badan atau Peradilan Tata Usaha Negara.

Upaya administratif yang mana keputusannya dapat digugat melalui peradilan Tata Usaha Negara adalah dalam menyelesaikan sengketa tata usaha negara dikenal adanya jalur atau upaya administratif, baik berupa banding administratif ataupun keberatan. Sesuai dengan dasar falsafah negara kita Pancasila, maka hendaknya sengketa tata usaha negara sedapat mungkin diselesaikan melalui upaya administratif, yang lebih bersifat musyawarah untuk 
Budi Aspani, Kompetensi Absolut Dan Relatif Peradilan Tata Usaha Negara Menurut UndangUndang Nomor 5 Tahun 1986 Jo. Undang-Undang Nomor 9 Tahun 2004

Halaman 344-352

mencapai mufakat. Tetapi bila keseluruhan upaya administratif yang tersedia telah digunakan, ternyata pihak yang bersengketa tetap belum merasa puas, maka barulah masalah itu diajukan dan digugat melalui Peradilan Tata Usaha Negara.

\section{DAFTAR PUSTAKA}

Amrah Muslimin, Beberapa Azas-azas dan Pengertian-pengertian Pokok Tentang Administrasi dan Hukum Administrasi, Alumni, Bandung, 1982.

Benyamin Mangkudilaga, Lembaga Peradilan Tata Usaha Negara, Ghalia Indonesia, Jakarta, 1982.

Djoko Prakoso, Peradilan Tata Usaha Negara, Liberty, Yogyakarta, 1988.

Marbun, SF., Moh. Mahfud MD., Pokokpokok Hukum Administrasi Negara, Liberty, Yogyakarta, 1987.

Marbun, SF., Peradilan Tata Usaha Negara, Liberty, Yogyakarta, 1982.

Muchsan, Pengantar Hukum Administrasi Negara Indonesia, Liberty, Yogyakarta, 1982.

Moh. Kusnardi, Harmaily Ibrahim, Pengantar Hukum Tata Negara Indonesia, PT. Pangeran Djayakarta, Offset, Jakarta, 1986.

Notonegoro, Pancasila Dasar Palsafah Negara, Bina Aksara, Jakarta, 1984.

Padmo Wahjono, Undang-undang Nomor 5 Tahun 1986 Tentang Peradilan Tata Usaha Negara Serta Penjelasannya, Ghalia Indonesia, Jakarta, 1987.

Sjachran Basah, Hukum Acara Peradilan Dalam Lingkungan Peradilan Administrasi (HAPLA), Rajawali Press, Jakarta, 1987.

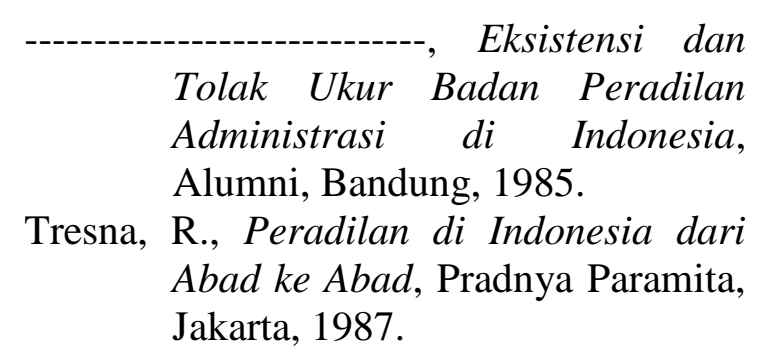

Tolak Ukur Badan Peradilan Administrasi di Indonesia, Jakarta, 1987. 